\title{
Clinical challenges with excipients in insulin formulations and role of concentrated insulin
}

\author{
K. D. Modi' ${ }^{1}$, Pradeep V. Gadge², Pradeep Jain ${ }^{3}$, Sudhir Pawar ${ }^{4}$, Ruchi D. Shah ${ }^{5}$, \\ Shahu A. Ingole ${ }^{5 *}$, Rishi Jain ${ }^{5}$
}

${ }^{1}$ Department of Endocrinology, Care Hospital, Nampally,

Hyderabad, India

${ }^{2}$ Department of Diabetology, Dr. Gadge's Diabetes Care Centre, Mumbai, Maharashtra, India ${ }^{3}$ Department of Medicine, Kashi Ganga Nursing Home, Varanasi, India

${ }^{4}$ Department of Pharmacology,

LTMMC and GH, Sion,

Mumbai, India

${ }^{5}$ Department of Medical Affairs, Wockhardt Ltd., Mumbai,

Maharashtra, India

Received: 04 February 2019

Accepted: 08 March 2019

\section{*Correspondence to:}

Dr. Shahu A. Ingole,

Email: singole@wockhardt.com

Copyright: () the author(s), publisher and licensee Medip Academy. This is an openaccess article distributed under the terms of the Creative Commons Attribution NonCommercial License, which permits unrestricted noncommercial use, distribution, and reproduction in any medium, provided the original work is properly cited.

\begin{abstract}
Most of the insulin formulations in clinical use contain phenol, meta-cresol or both as excipients. These excipients in insulin preparations provide stability and have antimicrobial properties. However, they are reported to be associated with undesirable side-effects especially localised allergic reactions. Amount of excipients injected per unit dose of insulin is a major determining factor in causation of these reactions. This review discusses the excipients in different insulin formulations available in India with potential of precipitating undesirable effects and the use of concentrated insulins to reduce these complications. To avoid the detrimental effects associated with excipients, removal of preservatives or use of insulin preparations devoid of excipients can be an option. Besides these approaches, one approach that can be considered is the use of concentrated insulin to reduce the volume of insulin dose and thereby the excipients. Concentrated insulins address the high insulin requirements of the growing population of patients with type 2 diabetes who require higher insulin doses. Concentrated insulins help in reduction of dose volume as well as amount of excipients injected per unit dose of insulin. U200 (concentrated r-DNA Human Insulin Premix 30/70-200 IU/ml) can be advantageous with better absorption from smaller quantity injected, lesser variability in absorption, lesser pain and discomfort due to smaller quantity, lesser chances of hypoglycaemia all of which can lead to better patient compliance. Thus, concentrated insulin U200 can be one of the alternatives to prevent/reduce clinical complications with excipients in insulins.
\end{abstract}

Keywords: Concentrated insulin, Excipients, Insulin, Meta-cresol, Preservatives

\section{INTRODUCTION}

Insulin is a cornerstone treatment in the management of diabetes mellitus. Since its discovery in 1922, there has been extensive research leading to the development of recombinant insulins. In 1982, first rapid-acting human insulin using recombinant DNA technology was commercialized. ${ }^{1}$ Other human insulins commercialized were neutral-protamine Hagedorn (NPH), lente and ultralente insulin. ${ }^{2}$ Analogs introduced later included rapidacting (lispro, aspart and glulisine) and long-acting (glargine, detemir and degludec) insulins. ${ }^{2}$ Insulin is active 
in the monomeric state. However, it assembles into dimers and hexamers in presence of zinc. ${ }^{3}$ Preparations of insulin contain phenolic excipients that serve two purposes: maintaining sterility of the solution and stabilization of the insulin molecule in the hexameric form to avoid aggregation. Of the most insulins available in the market, $58.33 \%$ contain metacresol, $33.33 \%$ contain both phenol and metacresol while rest contain other excipients (Table $1)$.

Table 1: Insulin formulations with excipient contents.

\begin{tabular}{|c|c|c|c|c|c|c|}
\hline Insulin & $\begin{array}{l}\text { Approval } \\
\text { year }\end{array}$ & $\begin{array}{l}\text { Meta- } \\
\text { cresol } \\
(\mathrm{mg} / \mathrm{mL})\end{array}$ & $\begin{array}{l}\text { Phenol } \\
\text { (mg/mL) }\end{array}$ & Zinc oxide & $\begin{array}{l}\text { Glycerine } \\
(\mathrm{mg} / \mathrm{mL})\end{array}$ & Other \\
\hline $\begin{array}{l}\text { Human } \\
\text { regular/soluble } \\
\text { insulin }{ }^{16} / \text { Human } \\
\text { insulin U500 }\end{array}$ & 1994 & 2.5 & - & $\begin{array}{l}0.017 \mathrm{mg} \\
\text { zinc ion }\end{array}$ & 16 & - \\
\hline Isophane Insulin ${ }^{17}$ & - & 1.6 & 0.65 & $\begin{array}{l}0.025 \mathrm{mg} \\
\text { zinc ion }\end{array}$ & 16 & $\begin{array}{l}\text { Dibasic sodium phosphate } \\
(3.78 \mathrm{mg}), \text { Protamine sulfate } \\
(0.35 \mathrm{mg})\end{array}$ \\
\hline Lispro $^{18}$ & 1996 & 3.15 & - & $\begin{array}{l}0.0197 \mathrm{mg} \\
\text { zinc ion }\end{array}$ & 16 & $\begin{array}{l}\text { Dibasic sodium phosphate } \\
(1.88 \mathrm{mg})\end{array}$ \\
\hline Aspart $^{19}$ & 2000 & 1.72 & 1.50 & $\begin{array}{l}19.6 \\
\mathrm{mg} / \mathrm{mL}\end{array}$ & 16 & $\begin{array}{l}\text { Disodium hydrogen phosphate } \\
\text { dihydrate }(1.25 \mathrm{mg} / \mathrm{mL}), \\
\text { sodium chloride }(0.58 \mathrm{mg} / \mathrm{mL})\end{array}$ \\
\hline Glulisine ${ }^{20}$ & 2004 & 3.15 & - & - & - & $\begin{array}{l}\text { Tromethamine }(6 \mathrm{mg} / \mathrm{mL}) \text {, } \\
\text { sodium chloride }(5 \mathrm{mg} / \mathrm{mL}) \text {, } \\
\text { polysorbate } 20(0.01 \mathrm{mg} / \mathrm{mL})\end{array}$ \\
\hline $\begin{array}{l}\text { Glargine }^{21}-10 \mathrm{~mL} \\
\text { vial }\end{array}$ & \multirow{2}{*}{2000} & 2.7 & - & $\begin{array}{l}30 \\
\mathrm{mcg} / \mathrm{mL}\end{array}$ & 20 & Polysorbate $20(20 \mathrm{mcg} / \mathrm{mL})$ \\
\hline $\begin{array}{l}\text { Glargine }^{21}-3 \mathrm{~mL} \\
\text { cartridge }\end{array}$ & & 2.7 & - & $\begin{array}{l}30 \\
\mathrm{mcg} / \mathrm{mL}\end{array}$ & 20 & - \\
\hline Detemir $^{22}$ & 2005 & 2.06 & & $\begin{array}{l}65.4 \\
\mathrm{mcg} / \mathrm{mL}\end{array}$ & 16 & $\begin{array}{l}\text { Disodium phosphate dehydrate } \\
(0.89 \mathrm{mg} / \mathrm{mL}), \text { sodium chloride } \\
(1.17 \mathrm{mg} / \mathrm{mL})\end{array}$ \\
\hline $\begin{array}{l}\text { Degludec }^{23}-100 \\
\mathrm{U} / \mathrm{mL}\end{array}$ & \multirow{2}{*}{2015} & 1.72 & 1.50 & $\begin{array}{l}32.7 \\
\mathrm{mcg} / \mathrm{mL}\end{array}$ & 19.6 & - \\
\hline $\begin{array}{l}\text { Degludec }^{23}-200 \\
\mathrm{U} / \mathrm{mL}\end{array}$ & & 1.72 & 1.50 & $\begin{array}{l}71.9 \\
\mathrm{mcg} / \mathrm{mL}\end{array}$ & 19.6 & - \\
\hline Glargine $300 \mathrm{U}^{24}$ & 2015 & $\begin{array}{l}2.7 / 1.5 \\
\mathrm{~mL}\end{array}$ & - & $\begin{array}{l}90 \mathrm{mcg} / 1.5 \\
\mathrm{~mL}\end{array}$ & $20 / 1.5 \mathrm{~mL}$ & - \\
\hline Inhaled insulin ${ }^{25}$ & 2014 & - & - & - & - & $\begin{array}{l}\text { Fumaryldiketopiperazine, } \\
\text { polysorbate } 80\end{array}$ \\
\hline
\end{tabular}

Most of the insulin formulations in clinical use contain either phenol, meta-cresol or both as excipients. ${ }^{2,4}$ Preservatives like phenol and meta-cresol in adequate concentration are added in insulin preparation to maintain stability. ${ }^{4}$ Though these excipients are non-active, they are essential components of the insulin formulations. However, they contribute to some undesirable effects on administration. Reports have suggested immunological reactions with excipients like meta-cresol.,

Allergic reactions with insulin administration are known since the introduction of the bovine and pork insulins. Localised allergic reactions are supposed to be majorly caused by excipients and additives in insulin preparations, while systemic allergic reactions are usually due to the insulin molecule itself. Allergic reactions with currently used insulins are reported in nearly $2 \%$ patients and less than one-third of these are reported to be directly related to the insulin itself. ${ }^{7}$ Beside allergic reactions, infusion site reactions occur in higher frequency in patients treated with insulins. ${ }^{8}$ Reports suggest that cell death and inflammatory reactions at the infusion site may be induced by phenol and meta-cresol present in formulation. ${ }^{9}$ Amount of excipients injected per unit dose of insulin is also a major determining factor to influence pharmacokinetic profile of insulin therapy. Increasing rates of insulin resistance are reported worldwide. ${ }^{10-12}$ This leads to requirement of higher doses of insulin in patients with diabetes receiving any of the 
current insulin formulations. Injection of large volumes of insulin may lead to poor or inconsistent insulin absorption. ${ }^{13}$ Therefore, use of concentrated insulin which provides a larger dose in a smaller quantity can be an alternative to conventional insulins. ${ }^{14}$ Concentrated insulins helps in reduction of dose volume as well as amount of excipients injected per unit dose of insulin. Here author discuss in brief the clinical challenges with excipients in insulins and how concentrated insulins can address them.

\section{Insulin formulations and their excipients}

Increasing interest in search of insulins to match basal and prandial endogenous insulin secretion led to the discovery of insulin analogs. These insulin analogs differ in their action profiles and risk of hypoglycemia. ${ }^{15}$ Each of the analogs contains different excipients. Table 1 provides the details of excipients present in each insulin formulations as per the approved label by the United States Food and Drugs Administration (USFDA). ${ }^{16-25}$ Figure 1 represents the meta-cresol and phenol contents of major insulin preparations.

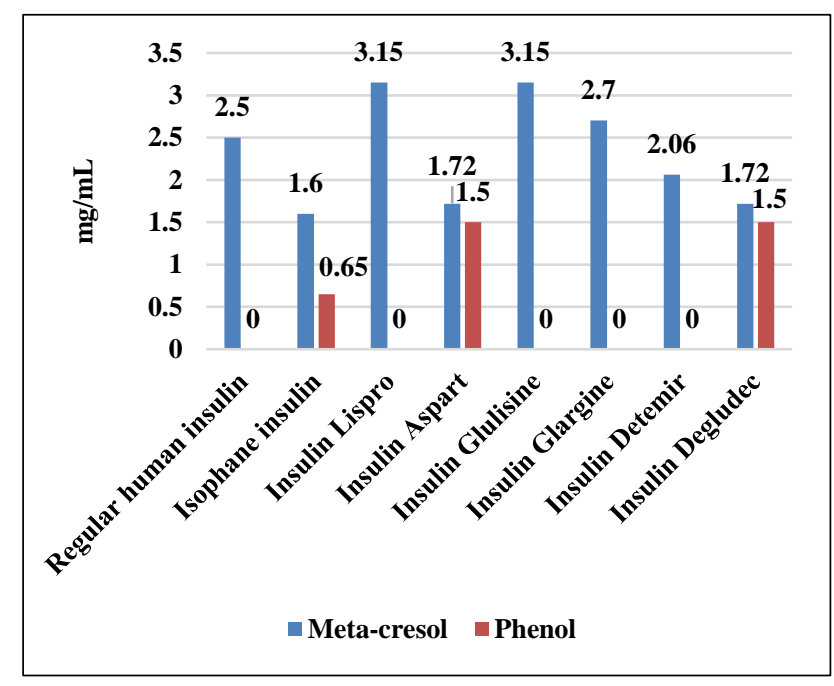

\section{Figure 1: Meta-cresol and phenol content of major insulin formulations.}

Insulin is known to be associated with immunological responses as patients may develop insulin autoantibodies (IAA). Insulin-related factors like purity, structure, storage conditions, formulation, excipients, dimer, and oxidation products as well as patient-related factors like age, HLA type, endogenous insulin, and delivery route may affect the development of IAA. ${ }^{26}$ Localised allergic reactions such as rashes at the injection site, are reduced by highly purified insulins. Systemic reactions are very rare which can occur at the start of insulin treatment or many years after. ${ }^{26}$ In these cases the allergy is usually due to the insulin molecule itself rather than additives such as the preservatives. Hypersensitivity reactions are also reported with insulin analogs like glargine and detemir. ${ }^{27}$
Excipients used along with the insulin act as antimicrobial preservative and insulin stabilizer., ${ }^{428}$ Probably the first reported case of protamine allergy was a 26-year old patient of insulin-dependent diabetes receiving insulin zinc protamine 20IU per day. In this post-nephrolithotomy patient, severe circulatory shock was reported with the use of $20 \mathrm{mg}$ protamine which was administered to reverse the heparin effect. ${ }^{29}$ Even in absence of the previous allergy to protamine, repeat administration in high-dose lead to an anaphylactic reaction. ${ }^{29}$ From India, recent report suggested protamine induced allergy in a 30 year old patient with type 2 diabetes. ${ }^{30}$ Thus, immune sensitization may occur with NPH insulin. Besides allergy to protamine, zinc-induced allergies have also been reported. Zinc-free insulin was found to be devoid of allergies. ${ }^{31,32}$

Phenolic excipients like phenol and meta-cresol can also induce the allergies. Recently, an allergic reaction to metacresol was reported in a 12-year old girl with type 1 diabetes. Meta-cresol-induced allergy was diagnosed because of the finding that the girl was allergic to all available insulin and meta-cresol was common to all of them. ${ }^{5}$ In another case, meta-cresol-induced allergy was reported in the adult patient with type 2 diabetes. ${ }^{6}$ An invitro study from Weber et al, reported that meta-cresol and phenol present in insulin were toxic to the fibroblast cell line L929 cells, human adipocytes and monocytic THP-1 cells to the same extent as the pure counterparts. ${ }^{9}$ Paiva et al, suggested that meta-cresol affects lipid bilayer and has an unusual preference for liquid ordered cholesterolsphingolipid-enriched domains. In neuronal cell-lines, they observed increased leak conductance with increase in the concentration of meta-cresol. ${ }^{33}$ Thus, cytotoxic and inflammatory actions of meta-cresol may underlie the undesirable effects associated with it.

\section{Therapeutic solutions for insulin excipient allergy}

Apart from use of alternative insulin preparation removal of preservatives is another option to avoid the detrimental effects associated with excipients. ${ }^{34}$ Eriksson $\mathrm{H}$ described a process for safe removal of preservatives without altering insulin concentration. From a $200 \mu \mathrm{l}$ insulin preparation, the adsorption of phenol and meta-cresol was found to be near complete (98\%) after passage for 5 seconds from a 15$\mathrm{mg}$ filter of ultra-stable zeolite Y (pore size $0.75 \mathrm{~nm}$ ) and modernite (pore size $0.70 \mathrm{~nm}$ ). The author observed no diminution in the insulin content of the filtrate. ${ }^{35}$ However, issues of stability and shelf-life might arise with the removal of preservatives. A newer insulin preparation free of meta-cresol and phenol inhaled insulin was recently approved by USFDA. ${ }^{25}$ Though there are no reports of hypersensitivity with inhaled insulin, reactions can occur due to human insulin. ${ }^{17}$ Besides these approaches, one theoretical approach that can be considered is the use of concentrated insulin to reduce the volume of insulin dose and thereby the excipients. Though excipients are considered as safe in the concentrations present in insulin preparations, repetitive or continuous subcutaneous insulin infusion (CSII) (e.g. with use of insulin pumps) leads to 
presence of meta-cresol and phenol in higher amounts at a local injection site. ${ }^{9}$ Therefore, use of concentrated insulin gives the benefit of reduction in amount of excipient injected with each unit of insulin. Combined with other approaches, this can be one of the alternatives to prevent/reduce clinical complications with excipients in insulins.

\section{Use of concentrated insulins}

Increasing insulin resistance may require insulin in the dose of more than 200 Units per day. According to American Diabetes Association there was a subset of patients having more extreme forms of insulin resistance than typical T2DM pattients. ${ }^{36}$ In recent years diabetes with obesity has been a common observation in outpatient clinics, such patients in long run eventually develop high resistance and require $\geq 2$ units of insulin per kilogram of body weight daily or $>200$ units of insulin daily to meet their insulin needs. Endocrine disorders like polycystic ovarian disease (PCOD), Cushing syndrome, Werners syndrome, Acanthosis nigricans, and temporary conditions like pregnancy, severe infection, and intake of steroids cause high insulin resistance thereby increasing total daily insulin requirement. Such patients require high volume of insulin, in multiple doses which was also painful thus leading to adherence issues. ${ }^{13}$ Therefore, use of concentrated insulins like U-200 can be a safer option wherein a small volume might suffice the need of multiple injections of lower strength insulins with lower risk of severe hypoglycemia. Concentrated insulins like insulin glargine $(300 \mathrm{U} / \mathrm{mL})$, lispro $(200 \mathrm{U} / \mathrm{mL})$, regular insulin $(500 \mathrm{U} / \mathrm{mL})$, and insulin degludec $(200 \mathrm{U} / \mathrm{mL})$ have marked their presence in the market along with a recent addition of regular insulin $(200 \mathrm{IU} / \mathrm{mL})$ and human premixed 30/70 (200 IU/mL) approved in India. ${ }^{14,37,38}$

U200 (concentrated r-DNA Human Insulin Premix 30/70 $200 \mathrm{IU} / \mathrm{ml}$ ) has potential advantage of covering prandial and basal insulin requirements. The use of such concentrated insulin can be advantageous with better absorption from smaller quantity injected, lesser variability in absorption, lesser pain and discomfort due to smaller quantity, lesser chances of hypoglycemia all of which can lead to better patient compliance. ${ }^{38}$

In a prospective, single-arm, open-label, multi-centre study by Thacker et al. presented at ADA 2018, assessing the efficacy and safety of U200 insulin in terms of 24-hour glucose profiling using Continuous Glucose Monitoring (CGM) in T2DM, it was observed that U200 premixed insulin demonstrated low intraday variability as measured by mean amplitude of glycemic excursion (MAGE) of $77.24 \mathrm{mg} / \mathrm{dl}$ and patients spending $62.35 \%$ of time within normal glucose limits, allowing for a more constant action with less frequent hypoglycaemic or hyperglycaemic excursions. ${ }^{39}$

Intentional insulin omissions are reported by more than half of respondents and regular omission by $20 \%$. Frequent daily injections are reported to be one of the independent factors significantly increasing the risk of insulin omission. ${ }^{40}$ Concentrated insulins address the high insulin requirements of the growing population of patients with T2DM who require higher insulin doses than permitted in a single injection with currently available pens. Smaller volume of injection allows fewer injections and thus overall enabling better patient adherence to therapy. Moreover, with the use of concentrated insulins, exposure to the lower quantities of excipients might reduce the likelihood of associated adverse effects (Figure 2). However, this theoretical hypothesis needs clinical confirmation in prospective studies.

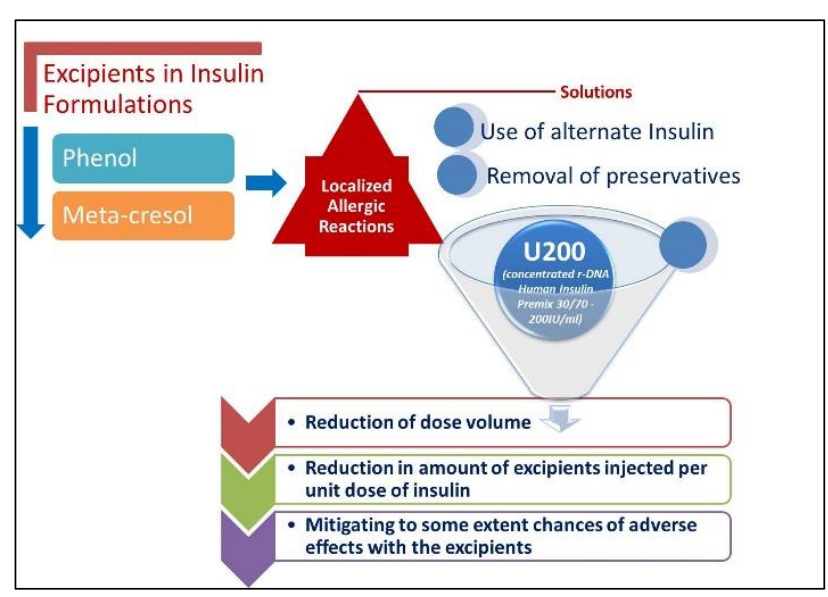

Figure 2: Solutions for mitigating allergic reactions caused by excipients in Insulin formulations.

\section{CONCLUSION}

The excipients in different insulin preparations like phenol and meta-cresol are especially known to be associated with localised allergic reactions. These excipients being the essential components of the insulin formulation, it is necessary to adapt to approaches that will help in prevention or avoidance of adverse effects with preservatives. Use of concentrated insulins may help reduce the volume of each insulin dose and thereby the quantity of the excipient, mitigating to some extent the chances of adverse effects with the excipients.

\section{Funding: No funding sources \\ Conflict of interest: None declared \\ Ethical approval: Not Required}

\section{REFERENCES}

1. Paulose KP. History of insulin. J Assoc Physicians India. 1999;47(2):255.

2. Gualandi-Signorini AM, Giorgi G. Insulin formulations - a review. Eur Rev Med Pharmacol Sci. 2001;5:73-83.

3. Derewenda U, Derewenda Z, Dodson GG, Hubbard RE, Korber F. Molecular structure of insulin: the insulin monomer and its assembly. Br Med Bull. 1989;45(1):4-18. 
4. Teska BM, Alarcõn J, Pettis RJ, Randolph TW, Carpenter JF. Effects of phenol and meta-cresol depletion on insulin analog stability at physiological temperature. J Pharm Sci. 2014;103(8):2255-2267.

5. Wheeler BJ, Taylor BJ. Successful management of allergy to the insulin excipient metacresol in a child with type 1 diabetes: a case report. J Med Case Rep. 2012;6(1):263.

6. Clerx V, Van Den Keybus C, Kochuyt A, Goossens A. Drug intolerance reaction to insulin therapy caused by metacresol. Contact Dermatitis. 2003;48(3):162-163.

7. Matheu V, Perez E, Hernández M, Díaz E, Darias R, González A et al. Insulin allergy and resistance successfully treated by desensitisation with Aspart insulin. Clin Mol Allergy. 2005 Dec;3(1):16.

8. Richardson T, Kerr D. Skin-related complications of insulin therapy: epidemiology and emerging management strategies. Am J Clin Dermatol. 2003;4(10):661-667.

9. Weber C, Kammerer D, Streit B, Licht AH. Phenolic excipients of insulin formulations induce cell death, pro-inflammatory signaling and $\mathrm{MCP}-1$ release. Toxicol Rep. 2015;2:194-202.

10. Do HD, Lohsoonthorn V, Jiamjarasrangsi W, Lertmaharit S, Williams MA. Prevalence of insulin resistance and its relationship with cardiovascular disease risk factors among Thai adults over 35 years old. Diabetes Res Clin Pract. 2010;89(3):303-308.

11. Ioannou GN, Bryson CL, Boyko EJ. Prevalence and trends of insulin resistance, impaired fasting glucose, and diabetes. J Diab Complications. 2007;21(6):363370 .

12. Bermudez V, Salazar J, Martinez MS, Castillo MC, Olivar LC, Calvo MJ et al. Prevalence and Associated Factors of Insulin Resistance in Adults from Maracaibo City, Venezuela. Adv Prev Med. 2016;2016:9405105.

13. Binder C, Lauritzen T, Faber O, Pramming S. Insulin pharmacokinetics. Diab Care. 1984;7(2):188-199.

14. Lamos EM, Younk LM, Davis SN. Concentrated insulins: The new basal insulins. Ther Clin Risk Manag. 2016;12:389-400.

15. Anthony K, Thomas S. Insulin analogues. C Bull Endocrinol Diab. 2002;4(1):18-21.

16. Actrapid 100 international units / $\mathrm{ml}$, Solution for Injection in a vial. Package leaflet : Information for the user. 2018. Available at : https://www.medicines.org.uk/emc/files/pil.3849.pdf. Accessed 8 January 2019.

17. FDA. AFREZZA® (insulin human) Inhalation Powder. Prescribing information 2014. Available at : https://www.accessdata.fda.gov/drugsatfda_docs/labe 1/2014/022472lbl.pdf. Accessed 8 January 2019.

18. FDA. HUMALOG® ((insulinlispro [rDNA origin] injection) Prescribing information 1996. Available at : https://www.accessdata.fda.gov/drugsatfda_docs/labe 1/2013/020563s115lbl.pdf. Accessed 8 January 2019.

19. FDA. NOVOLOG® (insulin aspart [rDNA origin] injection). Prescribing information 2000. Available at:https://www.accessdata.fda.gov/drugsatfda_docs/la bel/2015/020986s082lbl.pdf.

20. FDA. APIDRA® (insulin glulisine [rDNA origin] injection). Prescribing information 2004. Available at

https://www.accessdata.fda.gov/drugsatfda_docs/labe 1/2008/021629s015lbl.pdf.

21. FDA. LANTUS $®$ (insulin glargine [rDNA origin] injection). Prescribing information [Internet] 2000. Available at https://www.accessdata.fda.gov/drugsatfda_docs/labe 1/2009/021081s034lbl.pdf.

22. FDA. LEVEMIR $®$ (insulin detemir [rDNA origin] injection). Prescribing information 2005. Available from

https://www.accessdata.fda.gov/drugsatfda_docs/labe 1/2012/021536s037lbl.pdf.

23. EMA. TRESIBA® (insulin degludec [rDNA origin] injection).Summary of product characteristics 2013. Available https://www.ema.europa.eu/documents/productinformation/tresiba-epar-product-information_en.pdf.

24. FDA. TOUJEO ${ }^{\circledR}$ (insulin glargine U 300 injection). Prescribing information 2015. Available at : https://www.accessdata.fda.gov/drugsatfda_docs/labe 1/2018/206538s006lbl.pdf.

25. Angelo R, Rousseau K, Grant M, Leone-Bay A, Richardson P. Technosphere ${ }^{\circledR}$ insulin: defining the role of technosphere particles at the cellular level. J Diab Sci Tech. 2009;3(3):545-54.

26. Fineberg SE, Kawabata TT, Finco-Kent D, Fountaine RJ, Finch GL, Krasner AS. Immunological responses to exogenous insulin. Endocr Rev. 2007;28(6):625652.

27. Badik J, Chen J, Letvak K, So T-Y. Hypersensitivity Reaction to Insulin Glargine and Insulin Detemir in a Pediatric Patient: A Case Report. J Pediatr Pharmacol Ther. 2016;21(1):85-91.

28. Simpson AJH, Wuthiekanun V. Interaction of insulin with burkholderia pseudomallei may be caused by a preservative. J Clin Pathol. 2000;53(2):159-160.

29. Moorthy SS, Pond W, Rowland RG. Severe circulatory shock following protamine (An anaphylactic reaction). Anesth Analg. 1980;59:77-78.

30. Maheshwari M, Goyal D, Desouza P, Goyal RK. Spotted dermopathy in a diabetic patient due to insulin allergy. J Assoc Physicians India. 2004;52:926-927.

31. Feinglos MN, Jegasothy B V. "Insulin" Allergy Due To Zinc. Lancet. 1979;313(8108):122-124.

32. Ben Ammar I, Ksouri H, Trabelsi N,Mellouli F, Ben Mami F, Dakhli S et al. Generalized allergy due to zinc in insulin treated with zinc-free insulin. Acta Diab. 2012;49(3):239-241.

33. Paiva TO, Bastos AEP, Marques JT, Viana AS, Lima PA, de Almeida RFM. m-Cresol affects the lipid bilayer in membrane models and living neurons. Rsc Adv. 2016;6(107):105699-105712.

34. Akinci B, Yener S, Bayraktar F, Yesil S. Allergic reactions to human insulin: a review of current 
knowledge and treatment options. Endocrine. 2010 Feb 1;37(1):33-9.

35. Eriksson H. Removal of toxic preservatives in pharmaceutical preparations of insulin by the use of ultra-stable zeolite Y. Biotechnol Tech. 1998;12(4):329-334.

36. Elaince C. The Use of U-500 in Patients With Extreme Insulin Resistance. Diab Care. 2005;28(5):1240-44.

37. Painter NA, Sisson E. An overview of concentrated insulin products. Diab Spectr. 2016;29(3):136-140.

38. Tandon N, Kalra S, Balhara YP, Baruah MP, Chadha $\mathrm{M}$, Chandalia $\mathrm{HB}$ et al. Forum for injection technique and therapy expert recommendations, India: The Indian recommendations for best practice in insulin injection technique, 2017. Ind J Endocrinol Metab. 2017;21(4):600.
39. Thacker H, Kesavadev J, Singh G, Shukla K, Puppalwar G, Shrimanker R. Continuous Glucose Monitoring Guided Assessment of Concentrated U200 r-DNA Human Premix 30/70 Insulin. Diab. 2018; 67(Supplement 1).

40. Peyrot M, Rubin RR, Kruger DF, Travis LB. Correlates of Insulin Injection Omission. Diab Care. 2010;33(2): 240-245.

Cite this article as: Modi KD, Gadge PV, Jain P, Pawar S, Shah RD, Ingole SA, Jain R. Clinical challenges with excipients in insulin formulations and role of concentrated insulin. Int $\mathrm{J}$ Basic Clin Pharmacol 2019;8:821-6. 